\title{
Adenomatous Polyposis Coli Protein Deletion in Efferent Olivocochlear Neurons Perturbs Afferent Synaptic Maturation and Reduces the Dynamic Range of Hearing
}

\author{
Tyler T. Hickman, ${ }^{1}$ M. Charles Liberman, ${ }^{2,3}$ and Michele H. Jacob ${ }^{1}$ \\ ${ }^{1}$ Department of Neuroscience, Sackler Biomedical Graduate School, Tufts University, School of Medicine, Boston, Massachusetts 02111, ${ }^{2}$ Department of \\ Otology and Laryngology, Harvard Medical School, Boston, Massachusetts 02111, and ${ }^{3}$ Eaton-Peabody Laboratory, Massachusetts Eye \& Ear Infirmary, \\ Boston, Massachusetts 02111
}

\begin{abstract}
Normal hearing requires proper differentiation of afferent ribbon synapses between inner hair cells (IHCs) and spiral ganglion neurons (SGNs) that carry acoustic information to the brain. Within individual IHCs, presynaptic ribbons show a size gradient with larger ribbons on the modiolar face and smaller ribbons on the pillar face. This structural gradient is associated with a gradient of spontaneous rates and threshold sensitivity, which is essential for a wide dynamic range of hearing. Despite their importance for hearing, mechanisms that direct ribbon differentiation are poorly defined. We recently identified adenomatous polyposis coli protein (APC) as a key regulator of interneuronal synapse maturation. Here, we show that APC is required for ribbon size heterogeneity and normal cochlear function. Compared with wild-type littermates, APC conditional knock-out (cKO) mice exhibit decreased auditory brainstem responses. The IHC ribbon size gradient is also perturbed. Whereas the normal-developing IHCs display ribbon size gradients before hearing onset, ribbon sizes are aberrant in APC cKOs from neonatal ages on. Reporter expression studies show that the CaMKII-Cre used to delete the floxed APC gene is present in efferent olivocochlear (OC) neurons, not IHCs or SGNs. APC loss led to increased volumes and numbers of OC inhibitory dopaminergic boutons on neonatal SGN fibers. Our findings identify APC in efferent OC neurons as essential for regulating ribbon heterogeneity, dopaminergic terminal differentiation, and cochlear sensitivity. This APC effect on auditory epithelial cell synapses resembles interneuronal and nerve-muscle synapses, thereby defining a global role for APC in synaptic maturation in diverse cell types.
\end{abstract}

Key words: adenomatous polyposis coli protein (APC); hair cell; hearing; olivocochlear efferent; ribbon; synapse

Significance Statement

This study identifies novel molecules and cellular interactions that are essential for the proper maturation of afferent ribbon synapses in sensory cells of the inner ear, and for normal hearing.

\section{Introduction}

Ribbon synapses mediate transmission between cochlear inner hair cells (IHCs) and spiral ganglion neurons (SGNs). These synapses are specialized for fast, synchronized neurotransmitter release at stimulus onset, and sustained release for as long as the stimulus is present (Moser and Beutner, 2000; Khimich et al.,

\footnotetext{
Received Oct. 22, 2014; revised May 13, 2015; accepted May 15, 2015.

Author contributions: T.T.H., M.C.L., and M.H.J. designed research;T.T.H. performed research; M.H.J. contributed unpublished reagents/analytic tools; T.T.H. and M.H.J. analyzed data; T.T.H., M.C.L., and M.H.J. wrote the paper.

This work was supported by National Institutes of Health Grants NIDCD R01 DC008802 (M.H.J.), NINDS T32 NS061764 (M.H.J.; T.H., predoctoral trainee), NINDS P30 NS047243 (F.R. Jackson), NIDCD R01 DC00188 (M.C.L.), and P30 DC 05209 (M.C.L.).

The authors declare no competing financial interests.

Correspondence should be addressed to Dr Michele H. Jacob, Tufts University Department of Neuroscience, 136 Harrison Avenue, Boston, MA 02111. E-mail: Michele.Jacob@Tufts.edu.

DOI:10.1523/JNEUROSCI.4384-14.2015

Copyright $\odot 2015$ the authors $\quad 0270-6474 / 15 / 359236-10 \$ 15.00 / 0$
}

2005; Grant et al., 2010). Both onset and sustained responses are graded with stimulus intensity.

A single IHC makes synaptic contact with terminals from 5 to 30 SGNs. However, each SGN contacts a single IHC via a single ribbon synapse (Ruel et al., 2007; Liberman et al., 2011). SGNs display threshold sensitivities that can differ by several orders of magnitude (Taberner and Liberman, 2005). These threshold differences are critical to the impressive dynamic range of hearing. Threshold sensitivity is inversely correlated with spontaneous discharge rate (SR): high-SR fibers have low thresholds, while low-SR fibers have high thresholds. The SR gradient is mirrored by complementary gradients in synaptic morphology. Low-SR and high-SR fibers contact opposite sides of the IHC: synapses on the pillar (high-SR) side have large glutamate receptor patches opposite small presynaptic ribbons, whereas synapses on the modiolar (low-SR) side exhibit smaller glutamate receptor patches 
opposite larger ribbons (Liberman, 1982; Liberman et al., 2011; Yin et al., 2014). Although the SR gradient is critical for dynamic range of the auditory periphery, little is known about mechanisms that underlie differentiation of these synaptic gradients.

Ribbon synapse number and function are refined throughout development by numerous mechanisms, including the following: transient and sustained innervation of neonatal IHCs and SGN dendrites, respectively, by efferent olivocochlear (OC) neurons; purinergic and neurotrophic signals from supporting cells; thyroid hormone; and differential influx of $\mathrm{Ca}^{2+}$ into IHCs (Johnson et al., 2005; Sendin et al., 2007; Tritsch et al., 2007; Vetter et al., 2007; Roux et al., 2011; Zuccotti et al., 2012; Wong et al., 2013, 2014). In the adult cochlea, OC-SGN synapses are required for maintenance of SR range and ribbon size gradients, particularly large modiolar ribbons, as shown by surgical de-efferentiation (Liberman, 1990; Yin et al., 2014). Not yet defined are when and how, during development, ribbon-size gradients are generated, or the impact on cochlear function if they are not established.

Here, we investigated a role of adenomatous polyposis coli protein (APC) in ribbon synapse differentiation, based on its role in regulating maturation, density, function, and molecular composition of interneuronal synapses (Temburni et al., 2004; Rosenberg et al., 2008, 2010; Mohn et al., 2014). APC is a ubiquitously expressed scaffold and mRNA binding protein with multiple functions and binding partners (Fearnhead et al., 2001; Preitner et al., 2014). APC loss in neurons leads to excessive $\beta$-catenin levels and deregulation of both canonical Wntstimulated gene expression and cadherin synaptic adhesion complexes that, in turn, dynamically modulate synaptic density and maturation (Yu and Malenka, 2004; Salinas, 2012; Mohn et al., 2014). Intellectual disabilities and autism are associated with APC heterozygous gene deletions in humans (Heald et al., 2007; Zhou et al., 2007). APC loss in humans may impair hearing sensitivity (Lutz et al., 2006; Jones et al., 2010). Here, we show that APC conditional knock-out ( $\mathrm{CKO}$ ) mice exhibit reduced cochlear function, aberrant afferent synapse ribbon size gradients, and altered differentiation of efferent OC dopaminergic presynaptic inputs to SGN fibers. Our findings identify novel roles for APC and efferent $\mathrm{OC}$ inputs in establishing ribbon heterogeneity and normal hearing sensitivity.

\section{Materials and Methods}

Animals. APC cKO mice were generated by crossing APC lox468/ lox468 mice (Gounari et al., 2005) with CaMKII-Cre mice (Rios et al., 2001). APC fl/fl Cre-positive mice were used, and APC fl/fl Crenegative littermates served as wild-type (WT) controls (Mohn et al., 2014). CaMKII-Cre ROSA LacZ reporter mice were generated by crossing CaMKII-Cre mice with the ROSA26 Cre reporter strain (Soriano, 1999). CaMKII-Cre $\mathrm{mTmG}$ reporter mice were generated by crossing CaMKII-Cre mice with $\mathrm{mT} / \mathrm{mG}$ fluorescent reporter mouse (Muzumdar et al., 2007). All experiments used both male and female mice in nearly equal numbers. All procedures were in compliance with National Institutes of Health guidelines and approved by the Tufts University and the Massachusetts Eye \& Ear Infirmary Institutional Animal Care and Use Committee.

Cochlear function tests. Animals, 6-9 weeks of age, were anesthetized with ketamine (100 mg/kg, i.p.) and xylazine $(20 \mathrm{mg} / \mathrm{kg}$, i.p.). Auditory brainstem responses (ABRs) and distortion product otoacoustic emission (DPOAE) responses were measured in an acoustically and electrically shielded chamber at $30^{\circ} \mathrm{C}$. The Eaton-Peabody Laboratories (EPL) Acoustic System, EPL PXI System, and EPL Cochlear Function Test Suite were used to stimulate, record, and analyze cochlear function in the mice (http://www. masseyeandear.org/research/otolaryngology/investigators/laboratories/ eaton-peabody-laboratories/epl-engineering-resources/). To measure ABRs, needle electrodes were placed subdermally at the lower pinna (positive), the vertex of the skull (negative), and above the tail (ground). Short tone pips ( $4 \mathrm{~ms}, 0.5 \mathrm{~ms}$ rise-fall) were presented at half-octave intervals between 5.6 and $42 \mathrm{kHz}$, at $10-90 \mathrm{~dB}$ in $5 \mathrm{~dB}$ steps. ABR thresholds were defined as the minimum sound pressure level (SPL) at which an $\mathrm{ABR}$ waveform is readily discerned across $\geq 25 \mathrm{~dB}$ steps. For DPOAE measurements, two pure tones ( $\mathrm{f} 1$ and $\mathrm{f} 2$ ) were played through separate speakers, with $\mathrm{f} 2=1.2 \times \mathrm{f} 1$ and $10 \mathrm{~dB}$ less intense than $\mathrm{f} 1$. The DPOAE response amplitude at the $2 \mathrm{f} 1-\mathrm{f} 2$ distortion frequency was used to determine thresholds, defined as the calculated $\mathrm{f} 2$ value at which a $0 \mathrm{~dB}$ SPL DPOAE is produced.

Tissue preparation and staining. Animals were anesthetized with isoflurane followed by killing via cervical dislocation and decapitation. For epithelial whole mounts, cochleae were removed and immediately flushed with ice-cold PBS, followed by cold $4 \%$ paraformaldehyde (PFA) through cochlea windows and a hole in the cochlear apex. Cochleae were postfixed at $4^{\circ} \mathrm{C}$ for $3 \mathrm{~h}$ with gentle rotation. Postnatal day (P) 21 to adult (7-9 weeks old) cochleae were decalcified in cold PBS containing $0.125 \mathrm{M}$ EDTA under gentle rotation for $2 \mathrm{~d}$. P14 cochleae were decalcified for $1 \mathrm{~d}$, and $\mathrm{P} 0-\mathrm{P} 10$ cochleae did not require decalcification. The epithelial whole mounts were dissected from base to apex. For cryostat sectioning, cochleae were dissected after transcardial perfusion with ice-cold PBS, followed by $4 \%$ PFA, postfixation overnight at $4^{\circ} \mathrm{C}$ while rocking, decalcification, and infiltration with graded $10-30 \%$ sucrose in PBS over $3 \mathrm{~d}$ while rocking. Cochleae were rapidly frozen in cryostat embedding media, and sectioned ( $12 \mu \mathrm{m}$-thick slices) along the modiolar plane.

For $\beta$-galactosidase (LacZ) staining, cochleae were dissected after transcardial perfusion of PBS and 4\% PFA, postfixed for $1 \mathrm{~h}$, and stained in toto through the cochlea windows under gentle rocking at $37^{\circ} \mathrm{C}$ overnight, washed $3 \times$ for $10 \mathrm{~min}$ in $\mathrm{PBS}$, followed by postfixation and processing for whole-mount or cryostat sectioning as described above. The staining solution contained $1 \mathrm{mg} / \mathrm{ml} \mathrm{X}$-gal in $5 \mathrm{~mm} \mathrm{~K} 3 \mathrm{Fe}(\mathrm{CN}) 6,5 \mathrm{~mm}$ $\mathrm{K} 4 \mathrm{Fe}(\mathrm{CN}) 6.3 \mathrm{H}_{2} \mathrm{O}, 2 \mathrm{~mm} \mathrm{MgCl} 2.6 \mathrm{H}_{2} \mathrm{O}, 0.01 \% \mathrm{Na}$-deoxycholate, and 0.02\% NP-40 (Gómez-Casati et al., 2010).

For immunostaining, epithelial whole mounts were permeabilized by freezing in PBS at $-80^{\circ} \mathrm{C}$, followed by $1 \mathrm{~h}$ gentle rocking in blocking solution consisting of $1 \%$ Triton-X and 5\% normal horse serum (SigmaAldrich) in PBS. Whole mounts were then rocked in a humiditycontrolled chamber overnight at $37^{\circ} \mathrm{C}$ in primary antibody diluted in blocking solution, washed $3 \times$ for $5 \mathrm{~min}$ in blocking solution, incubated for $2 \mathrm{~h}$ at $37^{\circ} \mathrm{C}$ in secondary antibody diluted in blocking solution, washed $3 \times$ for $5 \mathrm{~min}$ in PBS, and mounted in Fluoromount-G (Southern Biotech). For cryostat section immunostaining, sections on slides were blocked for $1 \mathrm{~h}$ at $20^{\circ} \mathrm{C}$, stained in primary antibody solution for $2 \mathrm{~h}$ at $20^{\circ} \mathrm{C}$, washed $3 \times 5 \mathrm{~min}$, stained in secondary antibody solution for $1 \mathrm{~h}$ at $20^{\circ} \mathrm{C}$, washed $3 \times$ for $5 \mathrm{~min}$, and mounted using Fluoromount-G.

Primary antibodies used were as follows: rabbit anti-myosin VIIa (1: 200; Proteus BioSciences, 25-6790), mouse-IgG2a anti-GluR2 (1:1000; Millipore, MAB397), mouse-IgG1 anti-CtBP2/ribeye (1:200; BD Transduction Laboratories, 612044), rabbit anti-vesicular acetylcholine transporter (anti-VAT; 1:200; Abcam, ab68986), chicken anti-tyrosine hydroxylase (anti-TH; 1:1000; Abcam, ab76442), chicken anti-neurofilament H (1:1000; Millipore, AB5539), and chicken anti-GFP (1:500; Aves Labs, GFP-1020). Secondary antibodies used were as follows: DyLight 405 donkey anti-rabbit (1:400), Alexa 488 donkey anti-chicken (1:400), Alexa 488 goat anti-mouse-IgG2a (1:200), cyanine 3 antimouse-IgG1 (1:200), Alexa 647 donkey anti-chicken (1:400), Alexa 647 donkey anti-rabbit (1:400; all Jackson ImmunoResearch affinity-purified secondary antibodies). In addition, Hoechst 33258 dye (1:10,000; Invitrogen) was included in secondary antibody mixtures to stain nuclei. As controls for specific staining, secondary antibody only and omission of secondary antibody were used separately to verify background fluorescence. Autofluorescence was minimal in specimen preparation.

Confocal microscopy. All fluorescence microscopy was imaged using a Nikon A1R confocal system in the Tufts Center for Neuroscience Research Imaging Facility. The $\mathrm{mTmG}$ reporter mice were imaged using a Nikon $40 \times$ plan apochromat (APO) objective at $0.25 \mu \mathrm{m} /$ pixel resolution and $0.25 \mu \mathrm{m}$ steps. All micrographs used for ribbon volumetric analysis were imaged using a $60 \times$ plan APO objective at $0.10 \mu \mathrm{m} /$ pixel resolution and $0.25 \mu \mathrm{m}$ steps, at subsaturating gain. 
a
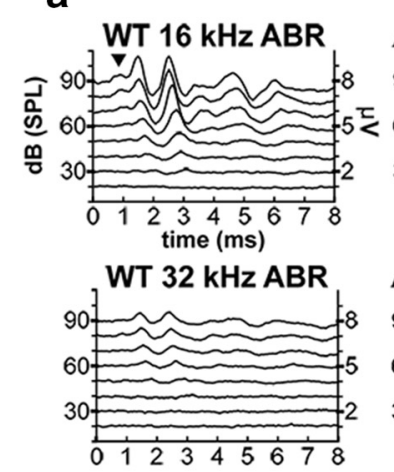

C

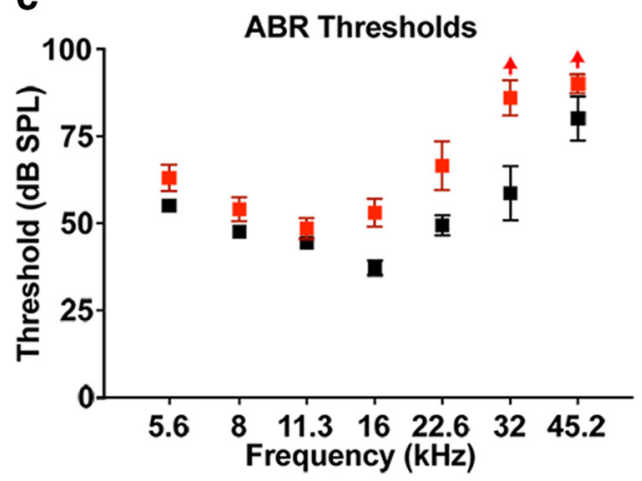

b
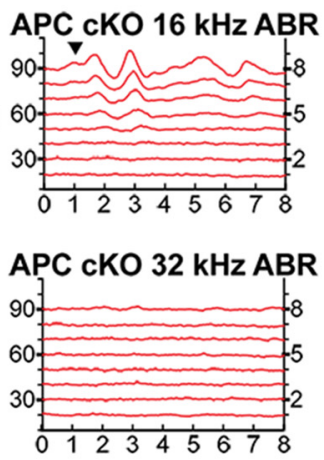

d

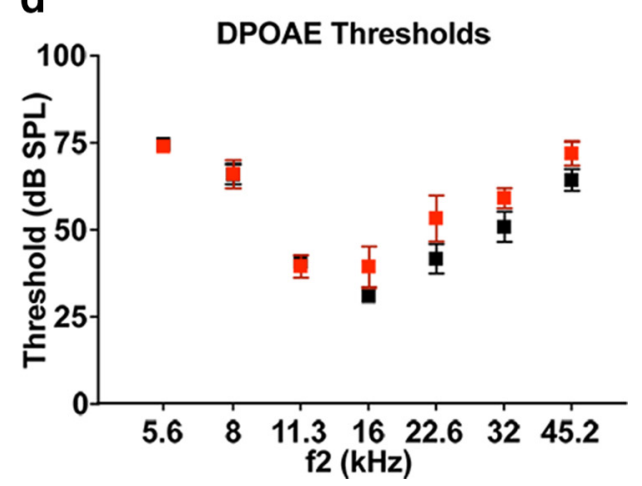

Figure 1. APC CKO mice have attenuated cochlear neural responses. $\boldsymbol{a}$, Representative ABR waveforms at 16 and $32 \mathrm{kHz}$ are reduced in APC cKO mice (right, red), compared with WT littermates (left, black). However, IHC-based summating potentials (arrowheads) appear unaffected. $\boldsymbol{b}$, APC cK0 mice display decreased ABR peak 1 amplitudes at both 16 and $32 \mathrm{kHz}{ }^{*} p<0.029$ and ${ }^{*} p<$ 0.024, respectively, Holm-Sidak $t$ test). Responses to $50 \mathrm{dBSPL}$ stimuli are shown: $n=10 \mathrm{APC}$ CKOs and 9 WTs at $6-9$ weeks old.c, APC cKO mice exhibit elevated ABR thresholds ( $p=0.001,2$-way ANOVA; $n=10$ APC cKOs and 9 WTs). $d$, OHC function is not significantly different from WT in APC cKO mice, based on DPOAE thresholds ( $p=0.104,2$-way ANOVA, $n=12$ APC cKOs and 13 WTs). Error bars in $\boldsymbol{b}-\boldsymbol{d}$ represent SEM.

Quantitative volumetric ribbon analysis. The cochlear region at the junction between the first and second cochlear turns, corresponding to $\sim 16 \mathrm{kHz}$ where, in WT mice, ribbon size gradients are most pronounced (Liberman et al., 2011), was imaged for quantitative ribbon analysis. Imaris software was used to analyze the $3 \mathrm{D} z$-stacks. The numbers and volumes of presynaptic ribbons and postsynaptic AMPAR clusters at IHC-SGN synapses, as well as the efferent OC dopaminergic and cholinergic presynaptic terminals on IHCs and SGN fibers were measured. Using the ribbons as a representative example, volumes were determined by defining a minimum threshold above local background and a minimum acceptable Gaussian distribution of voxel intensity around a given punctum, to minimize falsepositive noise, while allowing detection of small ribbons. Identical parameters were used within each age group, and similar parameters were used between each age. IHCs were delineated using MyoVIIa staining, while ribbon volumes were isolated using CtBP2 staining. Postsynaptic contacts were localized using a combination of GluA2 and neurofilament $\mathrm{H}$ immunomarkers. Every ribbon was quantified within each IHC, 4-7 IHCs were analyzed per animal, and 4-8 animals were analyzed per age and genotype. To minimize experimental variability, age-matched WT and APC cKO cochleae, often from littermates, were processed, stained, and imaged together. The average ribbon volume in WT IHCs was used to normalize modiolar and pillar ribbon volumes in both WT and cKO age-matched mice within a given staining group. To minimize observer bias, the volumes of the three ribbons closest to the cuticular plate on the modiolar face and on the pillar face within each IHC were averaged and normalized across each genotype in each staining group. Using this normalization, relative changes in pillar-face and modiolar-face ribbon volumes could then be compared between genotypes within each age, and the ribbon volume gradients compared as a function of developmental age.

Immunoblot analysis. Lysates were prepared from 12 pooled cochleae isolated from six APC cKO mice and six WT littermates. The immuno- blots were analyzed with antibodies to APC (Santa Cruz Biotechnology) and glyceraldehyde 3-phosphate dehydrogenase (GAPDH; Millipore Bioscience Research Reagents) as a loading control.

\section{Results}

Attenuated neural responses from adult APC cKO cochleae

To assess cochlear function, we measured the ABR, which reveals the magnitude of sound-evoked neural activity in the auditory periphery. Compared with WT littermates, APC cKO mice displayed elevated ABR thresholds across all frequencies tested $(p=$ 0.001, two-way ANOVA with repeated measures; Fig. 1a,c). Threshold shifts increased with increasing frequency. Indeed, APC cKO mice often had no detectable ABR response at 32 and $45.2 \mathrm{kHz}$ at the highest sound pressure presented ( $90 \mathrm{~dB}$ SPL). At high frequencies, the suprathreshold amplitude of wave 1 , the summed activity of the cochlear nerve, was also significantly reduced in the APC cKOs (Fig. 1b). In contrast, the summating potential (SP) arising presynaptically from the IHCs (Yuan et al., 2014) was unaffected by the targeted deletion (WT SP, $0.235 \pm$ $0.029 \mu \mathrm{V}$; cKO SP, $0.197 \pm 0.034 \mu \mathrm{V}$ for $16 \mathrm{kHz}$ and $80 \mathrm{~dB} \mathrm{SPL}$; $p=0.418$ unpaired $t$ test $)$.

Correspondingly, $\mathrm{OHC}$ function also appeared normal in the APC cKO ears. To assess OHC function, we measured DPOAEs, which arise from nonlinearities in mechanoelectric transduction, and are amplified by normal $\mathrm{OHC}$ function and transmitted back to the ear canal, where they can be measured. DPOAE thresholds in APC cKOs were not significantly different from those of WT littermates (Fig. $1 d ; p=0.104$, two-way ANOVA with repeated measures). Thus, threshold elevations in APC cKO mice appear to arise largely from dysfunction in synaptic transmission be- 
a
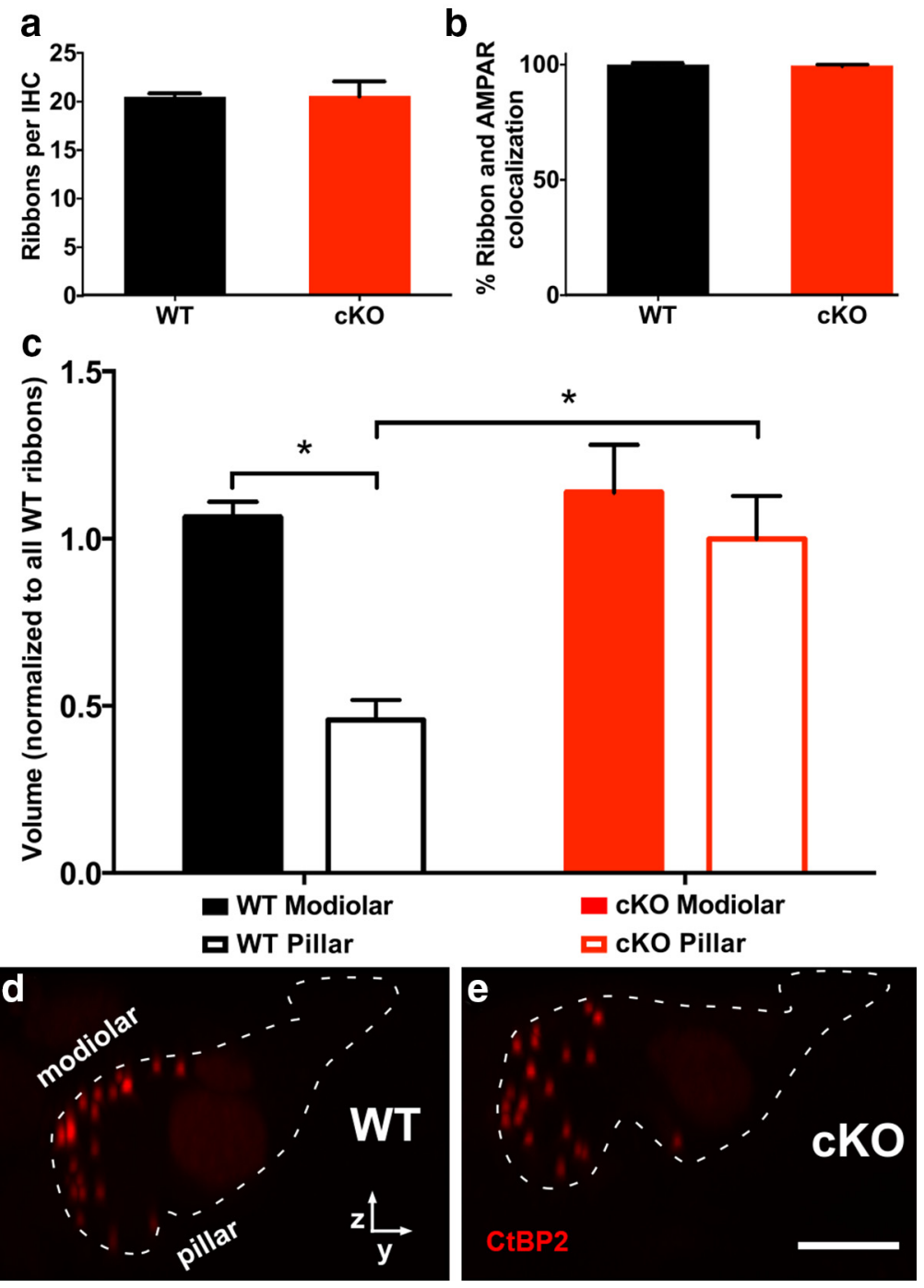

Figure 2. IHCS in APC CKOs display normal ribbon numbers but lack the normal ribbon-size gradient. $\boldsymbol{a}$, IHC ribbon counts (CtBP2-positive puncta) at the $16 \mathrm{kHz}$ region in APC cKO mice are similar to those in WT mice. $\boldsymbol{b}$, In both APC cKOs and WTs, virtually all ribbons form synapses, i.e., are closely juxtaposed to GluA2-positive puncta. c, APC cKOs lack the normal gradient of large modiolar to small pillar ribbons, and have significantly larger pillar-face ribbon volumes $\left({ }^{*} p<0.05\right.$, Mann-Whitney test). $\boldsymbol{d}, \boldsymbol{e}$, Confocal micrographs of ribeye (CtBP2)-immunolabeled ribbons at synaptic pole of IHCs (outlined in white based on MyoVIla staining) in $z$-stacks, oriented on the $y$ - $z$-axis, show the lack of ribbon size gradient, and increased size of pillar-face ribbons in APC cKOs compared with WT littermates. Scale bar, $10 \mu \mathrm{m} . n=4-7 \mathrm{IHCs}$ from each of four WT mice and five APC cKO mice. Error bars in $\boldsymbol{a}$-c represent SEMs.

tween IHCs and the cochlear nerve terminals that synapse with them.

\footnotetext{
Altered ribbon size gradients in adult APC cKO IHCs

To look for changes in synaptic morphology, we immunostained the cochlear sensory epithelium for CtBP2, a major component of presynaptic ribbons (Schmitz et al., 2000; Zenisek et al., 2003), and quantified the number and volume of IHC ribbons at the $16 \mathrm{kHz}$ region. We focused on this region because ribbon size gradients are most pronounced here in WT mice (Liberman et al., 2011). APC cKOs and WTs (6-9 weeks old) displayed similar numbers of ribbons per IHC (Fig. 2a), and mean values $(\sim 20)$ were consistent with those in previous studies in mice (Liberman et al., 2011). To test for the presence of postsynaptic AMPAR patches on the SGN fibers at sites apposing presynaptic ribbons, we double-stained for the GluA2 subunit. Nearly every ribbon in IHCs of WTs (99.7\%) and APC cKOs (99.2\%) was closely juxtaposed to
}

an AMPAR cluster (Fig. 2b). Thus, the reduction in $\mathrm{ABR}$ responses in $\mathrm{APC} \mathrm{CKO}$ mice is not caused by a loss of afferent ribbon synapses.

Within a single IHC, ribbon synapses normally exhibit a size gradient, with larger ribbons on the modiolar side and smaller ribbons on the pillar side (Liberman et al., 2011; Yin et al., 2014). Fibers synapsing on the modiolar face tend to have high thresholds and low spontaneous rates (SRs), while fibers synapsing on the pillar face have low thresholds and high SRs (Liberman, 1982). To determine whether the ribbon size gradient is altered in APC cKO IHCs, we compared ribbon volumes on the modiolar versus pillar faces in the $16 \mathrm{kHz}$ region. To compare data from ears processed and imaged on different days, volumes in cKOs were normalized to the average ribbon size from WTs processed on the same day. The ribbon size gradient was readily detected in WT mice (Fig. $2 c, d$ ); however the gradient was absent in APC cKOs (Fig. 2c,e). Ribbons on APC cKO modiolar and pillar faces were similar in volume, with APC cKO pillar ribbons approximately twice the volume of WT pillar ribbons (Fig. 2c). Since large ribbons normally indicate high-threshold, low-SR SGNs, the ribbon dysmorphology could reflect the ABR threshold elevations seen in APC $\mathrm{cKO}$ mice (Fig. 1).

\section{Cellular site of cochlear APC deletion}

To identify mechanisms underlying the ribbon synapse changes in $\mathrm{APC}$ cKOs, we first confirmed that expression of CaMKII Cre recombinase excises the floxed APC gene in APC cKO cochlea. We show a marked reduction of APC protein levels, as detected by immunoblotting (Fig. 3a). Next, we identified the cell types in the adult cochlea that express the CaMKIICre and lose APC. We used two reporter mouse lines: ROSA LacZ mice, for brightfield histological studies, and membranebound (m) dTomato-mGFP (mTmG) mice (Muzumdar et al., 2007) for fluorescent studies. Previous analyses of CaMKII-Cre expression in the developing mouse brain showed expression chiefly in postmitotic, glutamatergic neurons, beginning neonatally and reaching peak expression in the third postnatal week (Rios et al., 2001). Surprisingly, neither IHCs nor SGNs, both of which are glutamatergic, were sites of CaMKII expression (Fig. $3 b-g$ ). Signal was never observed in IHCs or OHCs (Fig. $3 e-g$ ). Few Cre-positive cells were detected among the thousands of SGNs in epithelial whole mounts of CaMKII-Cre ROSA mice (Fig. $3 b$ ). Similarly, cryostat sections of CaMKII-Cre mTmG cochleae showed an overwhelming predominance of Cre-negative (red) SGNs (Fig. 3c). In contrast, CaMKII-Cre was expressed in fibers of the OC efferent system and in a subset of nonsensory support cells of the organ of Corti. The signal in the OC fibers is visible in the region of the spiral ganglion, where a small subset of the 
fibers directed toward the organ of Corti are GFP-positive (Fig. 3c, yellow arrowheads), and in the region under the IHC (Fig. 3e, inset), where the OC fibers spiral in the inner spiral bundle (ISB). Supporting cell expression is seen in the low-power view of the CaMKII-Cre ROSA LacZ mice (Fig. $3 b, b^{\prime}$ ). In the high-power confocal images from the $\mathrm{mTmG}$ mice, the reporter signal is clearly present in inner and outer pillar cells, and in Deiters' cells underneath the OHCs (Fig. 3d-g).

To determine the developmental time course of APC deletion, we examined CaMKII-Cre expression in $\mathrm{mTmG}$ reporter mice at weekly intervals from $\mathrm{P} 0$ to P28 (Fig. 4). At P0, expression was confined to OC neurons, as seen in the intraganglionic spiral bundle within the spiral ganglion, the ISB beneath the IHCs, and the osseous spiral lamina that connects them (Fig. 4a,e). At P7-P9, when OC fibers contact both IHCs and SGN terminals (Simmons et al., 2011), Cre expression is readily detected in the ISB (Fig. $4 b, g, h$ ), and in the region of the cochlear nucleus where the central axons of the auditory nerve are present (Fig. 4f). At this age, Cre expression is also observed in OC efferents crossing the nascent tunnel of Corti (Fig. 4b). CaMKII-Cre expression in supporting cells appears later, beginning at P14 when supporting cell staining is patchy, with signal in $\sim 1$ of 30 cells (Fig. $4 c$ ). By P28, when the cochlea is morphologically and physiologically identical to the adult, the great majority of pillar and Deiters' cells are positive for CaMKII-Cre, and expression remains in the OC fibers in the ISB (Fig. $4 d$ ). Previous reports of APC heterozygous gene deletion in mouse cochlea supporting cells show changes in microtubule cytoskeleton dynamics and reduced bundling (Mogensen et al., 2002). Such changes are not apparent in APC cKOs, whose cochlear morphology and mechanoelectrical transduction, assessed by measuring DPOAEs, appear normal. Overall, the restricted expression of CaMKII-Cre in two cell types, with different ages of onset, makes it important to determine when during development the ribbon gradients normally appear and whether they ever appear in the APO cKO ears.

\section{Ribbon size gradients in IHCs from neonatal WT and APC cKO mice}

The ribbon size gradient is already present in WT IHCs at P9 (Fig. $5 a$ ), before IHCs respond to sound stimuli. At this age, the number of ribbons is higher $(27.1 \pm 1.06 / \mathrm{IHC})$ than at P28 (20.1 \pm $0.850 / \mathrm{IHC}$ ) and adult (7-9 weeks, $20.4 \pm 0.212 / \mathrm{IHC})$. In WT P9, $\mathrm{P} 28$, and adult mice, modiolar-face ribbons are larger than pillarmice, $n=8$ (re + and 8 WT)

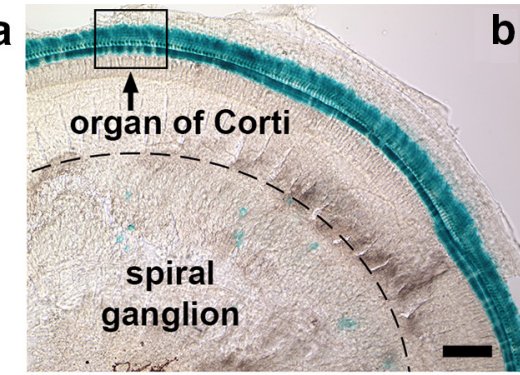

b
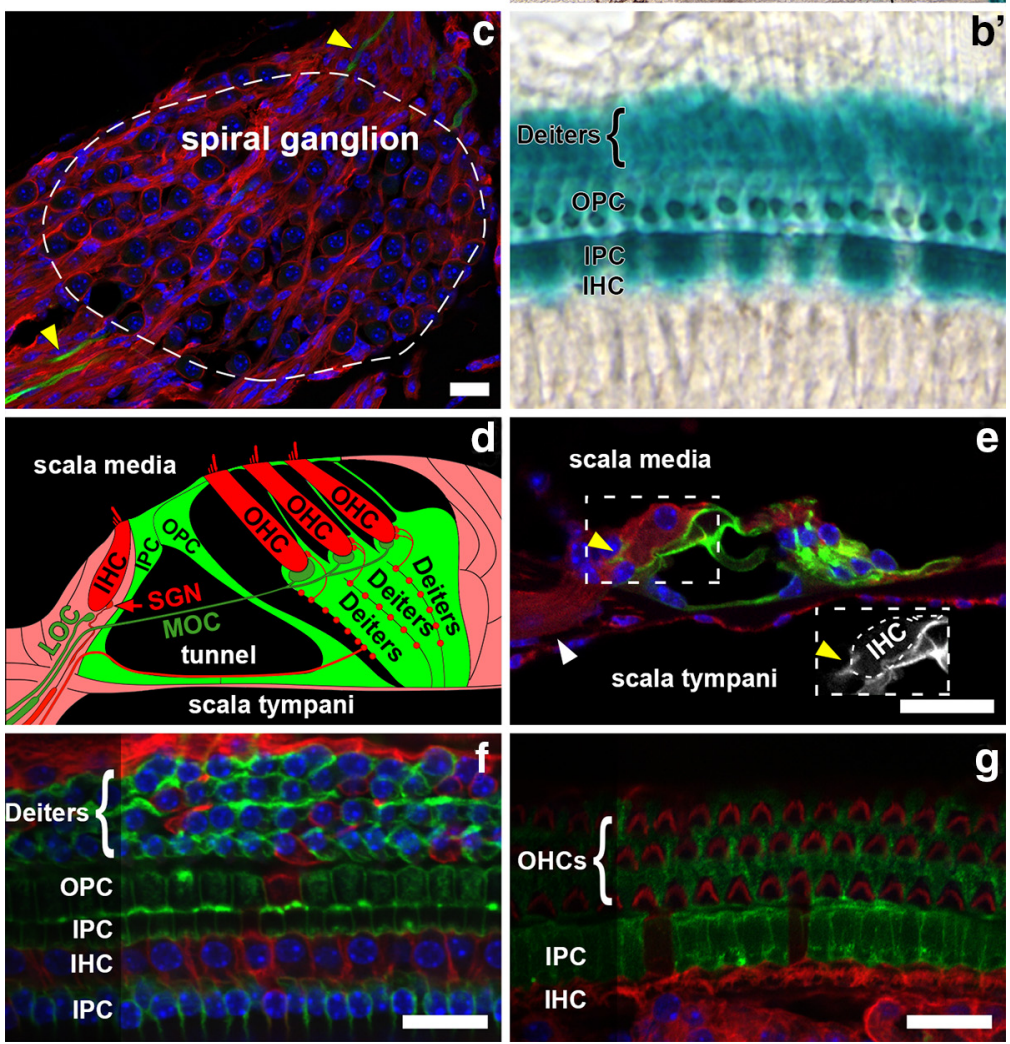

Figure 3. CaMKII-Cre recombinase expression is restricted to $O C$ neurons and supporting cells of the adult cochlea. $\boldsymbol{a}$, Immunoblotting shows decreased APC protein levels in cochlear lysates from pooled APC cKOs, compared with that of WT littermates (6 mice, 12 cochleae in each lane). GAPDH, as a loading control. $\boldsymbol{b}$, CaMKII-Cre expression (xgal, blue) is robust in the organ of Corti and sparse in the spiral ganglion, as shown in a cochlea epithelial whole mount of an adult ROSA-LacZ reporter mouse. $\boldsymbol{b}^{\prime}$, Inset, A small region of the organ of Corti outlined in $\boldsymbol{b}$, is enlarged to more clearly show labeling of support cells, including inner pillar cells (IPC), outer pillar cells (OPC), and Deiters' cells. IHCs are not labeled. c, No CaMKII-Cre-positive SGNs (green, mGFP) are present among the abundant Cre-negative SGNs (red, mTomato) in this representative cryostat section of an adult mTmG Cre reporter mouse. Crepositive (green, $\mathrm{mGFP}$ ) processes (yellow arrowheads), likely efferent $\mathrm{OC}$ axons, are seen entering and leaving the ganglion. Cell nuclei are labeled (blue, HOECHST). $\boldsymbol{d}$, Schematic diagram of CaMKII-Cre (green) expression in LOC fibers to the IHC area, medial OC (MOC) fibers to the $\mathrm{OHC}$ area, as well as selected supporting cells, including IPCs, OPCs, and Deiters' cells. $\boldsymbol{e}$, Representative cryostat section from adult mTmG reporter mouse showing CaMKII-Cre expression pattern in the organ of Corti. Cre-positive (green, mGFP) IPCs, OPCs, Deiters' cells, and spiraling LOC inputs (yellow arrowheads); (re-negative (red, mTomato) IHCs, OHCs, and SGN fibers (white arrowhead). Lower right inset, Higher-magnification view of Cre-positive (green, mGFP) LOC terminals (yellow arrowhead). $\boldsymbol{f}$ - $\boldsymbol{g}$, CaMKII-Cre-positive (green, mGFP) IPCs, OPCs, and Deiters' cells, and Cre-negative (red, mTomato) IHCs and OHCs in confocal images focused at the middle of the tunnel of Corti $(\boldsymbol{f})$ and the roof of the tunnel of Corti $(\boldsymbol{g})$. The V-shaped stereocilia $(\boldsymbol{g}$; red, mTomat0) are seen on (re-negative OHCs. Scale bars: $\boldsymbol{a}, 50 \mu \mathrm{m} ; \boldsymbol{b}, \boldsymbol{e}-\boldsymbol{g}, 20 \mu \mathrm{m}$. (ROSA LacZ mice, $n=6$ Cre + and 8 WT; mTmG

face ribbons (Fig. 5a). Additionally, average ribbon size increases in the developing IHC, reducing the relative size difference between the cuticular-most modiolar-face and pillar-face ribbons compared with average ribbon volume per IHC, from P9 through adulthood (Fig. 5a).

As in WTs, APC cKOs exhibit an increased number of ribbons at P9 $(28.3 \pm 1.44 / \mathrm{IHC})$, compared with P28 (20.6 $\pm 0.360 / \mathrm{IHC})$ and adult $(20.5 \pm 0.691 / \mathrm{IHC})$ ribbon numbers. At $\mathrm{P} 9$, pillar-face 

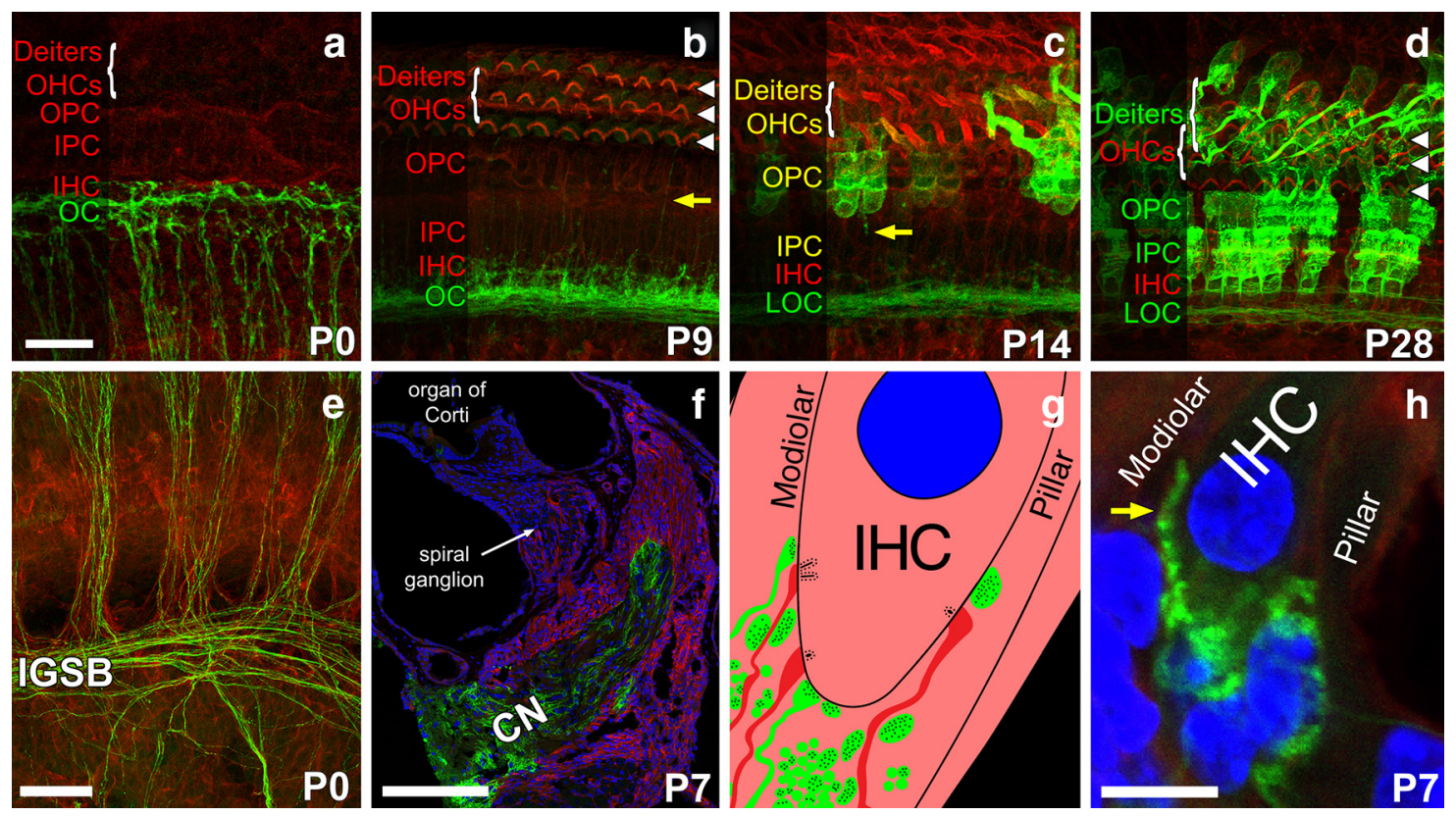

Figure 4. CaMKII-Cre is expressed in $O C$ fibers at PO, and later at P14 in supporting cells. $\boldsymbol{a}, \boldsymbol{e}, A t P O$, Cre expression is restricted to $O C$ fibers, as seen in the ISB below IHCs (a), and in the intraganglionic spiral bundle (e; IGSB). $\boldsymbol{b}, \boldsymbol{f}, \boldsymbol{h}, A$ A P7-P9, expression is strong in OC fibers, as seen in the ISB in whole mounts $(\boldsymbol{b})$ and cross sections ( $\boldsymbol{h}$ ) of the organ of Corti; in OC fibers crossing the tunnel of Corti ( $\boldsymbol{b}$, yellow arrow), and contacting IHCs ( $\boldsymbol{h}$, yellow arrow), as well as in the interstitial region of the cochlear nucleus (f; CN). There is no expression in hair cells (e.g., $\boldsymbol{b}, 3$ white arrowheads). c, At P14, CaMKII-Cre expression is seen in medial 0C fibers (yellow arrow) and now appears in a subset of inner pillar cells (IPCs), outer pillar cells (OPCs), and Deiters' cells. $\boldsymbol{d}$, By P28, expression is seen in a larger number of these same supporting cell types. $\boldsymbol{g}$, Schematic cross section shows Cre-positive 0 C terminals (green, mGFP) surrounding the synaptic pole of the IHC. Scale bars, $\boldsymbol{a}-\boldsymbol{d}, 20 \mu \mathrm{m} ; \boldsymbol{e}, 50 \mu \mathrm{m} ; \boldsymbol{f}, 200 \mu \mathrm{m} ; \boldsymbol{h}, 20 \mu \mathrm{m}$. (P0: $n=4 \mathrm{Cre}+, 3 \mathrm{WT} ; \mathrm{P} 7: n=10 \mathrm{Cre}+, 11 \mathrm{WT} ; \mathrm{Pg}: n=10 \mathrm{Cre}+, 11 \mathrm{WT} ; \mathrm{P} 14: n=2 \mathrm{Cre}+, 3 \mathrm{WT} ; \mathrm{P} 21: n=7 \mathrm{Cre}+, 5 \mathrm{WT} ; \mathrm{P} 28: n=10$ (re+, 5 WT).

ribbons are significantly larger in APC cKOs, compared with WT littermates $(p=0.0109$, Mann-Whitney test; Fig. $5 a)$. The modiolar-face ribbons are larger still, but not different in size between APC cKOs and WTs (Fig. 5a). Furthermore, while WT mice display a clear ribbon size gradient, APC cKO mice do not; i.e., their modiolar ribbons are not significantly larger than pillar ribbons (WT $p=0.0003, \mathrm{cKO} p=0.0556$, Mann-Whitney test). These results demonstrate that ribbon sizes are aberrant by P9 in APC cKO mice, when APC deletion is restricted to the OC system; it is not yet deleted in the supporting cells, which occurs later, in the second and third postnatal weeks (Fig. $4 c, d$ ). The pillar ribbons remain larger at P28 and adult ages in APC cKOs compared with WTs (both $p=0.016$, Mann-Whitney test). The ribbon size gradient remains absent in APC cKOs at P28 ( $p=$ 0.413 ) and adulthood ( $p=0.667$, Mann-Whitney test; Fig. $5 a$ ). Overall, in WTs, modiolar-face ribbons are $89 \%$ larger than pillar-face ribbons at $\mathrm{P} 9,43 \%$ larger at $\mathrm{P} 28$, and $132 \%$ larger in adulthood (6-9 weeks), whereas in APC cKOs, the size difference is reduced to $53 \%$ larger at $\mathrm{P} 9,19 \%$ larger at $\mathrm{P} 28$, and $13 \%$ larger in adulthood. Complementarily, APC cKO AMPAR patches on SGN fibers trend to smaller, but not significantly different, sizes in cKOs, compared with WT littermates, at immature (P9, $~ 17 \%$ smaller) and mature ages (7-9 weeks, $\sim 27 \%$ smaller; Fig. $5 b$ ). Thus, loss of APC from OC terminals in the postnatal ear leads to delayed refinement of modiolar ribbon sizes, incomplete refinement of pillar ribbon sizes, loss of the ribbon size gradient within IHCs, and a trend to smaller postsynaptic AMPAR cluster volumes.

Efferent $O C$ presynaptic terminals are altered in neonatal APC cKO cochleae

Because the loss of IHC ribbon size gradients correlates temporally with CaMKII-Cre-mediated deletion of APC in efferent OC neurons, we looked for changes in OC inputs to the cochlea in APC cKO neonates. We immunostained both cholinergic (VAT) and dopaminergic $(\mathrm{TH})$ efferent subgroups that innervate IHCs and SGN fibers, respectively, at this age. The presynaptic terminals are readily observed throughout the ISB (Fig. $6 a, b$ ). We quantified their number and volume in the $16 \mathrm{kHz}$ region of $\mathrm{P} 10$ cochleae. The cholinergic efferent OC terminals trended to reduced volumes and density in APC cKO mice, compared with WTs (but were not significantly different, unpaired $t$ test; Fig. $6 a-c)$. In contrast, the inhibitory, dopaminergic efferent terminals displayed significantly increased volumes and density in the cKOs (Fig. $6 a, b, d$ ). These structural changes are consistent with reduced ABRs in the APC cKO mice (Ruel et al., 2001; Groff and Liberman, 2003).

\section{Discussion}

Our findings suggest that APC and efferent OC inputs are regulators of ribbon synapse morphology and threshold sensitivity in the developing mammalian inner ear. APC cKO mice exhibit elevated ABR thresholds across the frequency range of mouse hearing. Hair cell function appears normal, based on summating potentials that arise presynaptically from IHCs (Yuan et al., 2014) and DPOAEs that reflect mechanoelectric transduction and cochlear amplification mediated by OHCs. On the other hand, IHC afferent ribbon synapses are structurally altered in APC cKOs. By $\mathrm{P}$ 9, ribbons are aberrantly large, particularly on the pillar face of the sensory cell, and the ribbon size gradient, established in WT mice by this early age, is reduced in APC cKOs. Thus, the decreased cochlear sensitivity of APC cKOs appears to arise from dysfunction of the primary synapse between IHCs and SGNs.

The postsynaptic component of IHC ribbon synapses, type-I SGNs, make up $95 \%$ of the auditory nerve that carries auditory information to the brain (Spoendlin, 1972). Each type-I SGN 
terminal contacts a single IHC at a single active zone, to which a single presynaptic ribbon is typically anchored (Liberman, 1982). The ribbon size gradient in normal IHCs is mirrored by a complementary gradient in the sizes of postsynaptic AMPAR clusters, and these morphological gradients may play a role in the threshold sensitivity gradients observed in recordings from SGN central axons (Liberman, 1978; Tsuji and Liberman, 1997; Taberner and Liberman, 2005). On the modiolar face of the IHC, large ribbons appose small AMPAR clusters on SGN dendrites, whereas on the pillar face, small ribbons appose large AMPAR clusters (Liberman et al., 2011; Yin et al., 2014). Pillar-face small-ribbon synapses correspond to SGNs with high SRs and mediate responses at low SPLs, whereas modiolarface large-ribbon synapses correspond to SGNs with low SRs and mediate responses to higher-level stimuli (Liberman, 1982). Thus, the gradients of synapse size and threshold sensitivity in the normal ear are necessary for the large dynamic range of the auditory periphery.

APC cKO mice exhibit elevated thresholds, and aberrantly large ribbons on the pillar face, leading to loss of ribbon size gradients. In addition, the postsynaptic AMPAR clusters of APC cKO mice trend to smaller volumes compared to those of WT littermates. This afferent synapse dysmorphology is consistent with the reduced cochlear sensitivity of APC $\mathrm{cKO}$ mice. However, ribbon dysmorphology does not always produce threshold shifts, as observed in mature cochleae after acoustic overstimulation that causes permanent changes in ribbon morphology despite only reversible elevations of threshold (Lin et al., 2011; Furman et al., 2013). Ribbon sizes therefore seem plastic. As yet undefined is whether simultaneous changes occur in active zone or postsynaptic organization following noise exposure, and which architectural properties of the afferent synapse are critical for recovering lowthreshold responses.

The ribbon size gradient is present in the mouse cochlea middle turn by $\mathrm{P} 9$, an age when IHCs do not yet respond to sound. Instructive cues for the ribbon size gradient are already present at neonatal ages. In contrast, the ribbon size gradient is perturbed and AMPAR volume trends to smaller sizes by P9 in APC cKOs. The structural and functional changes define APC as a key molecule for normal cochlear function.

Developmental analysis of cochlear CaMKII-Cre expression suggested that APC deletion is targeted to efferent OC neurons, but not IHCs, OHCs, SGNs, or supporting cells by P0 and P9. Thus OC efferents appear to be the cell type in which APC functions to regulate afferent ribbon synapse morphology. At neonatal ages, medial OC efferents transiently establish nicotinic

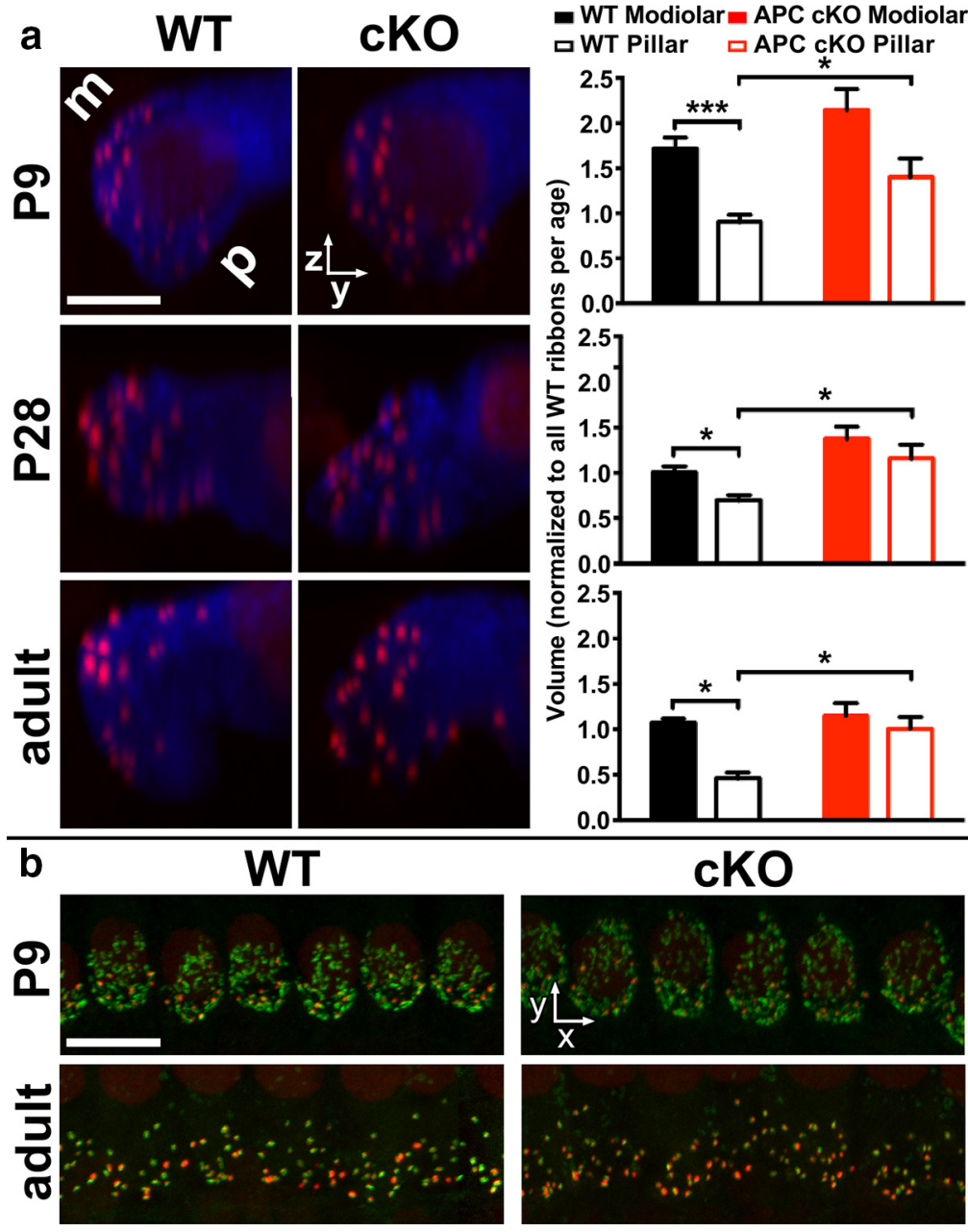

Figure 5. Ribbon size gradient appears by P9 in WT mice, but not in APC cK0 mice. $a$, Left, Confocal micrographs of ribeye (red, tBP2)-immunostained ribbons at synaptic poles of individual IHCs (blue, MyoVIlla) in $z$-stacks, oriented on the $y$-z-axis. Right, iolar (m) ribbon to small pillar ( $\mathrm{p}$ ) ribbon, is present prehearing $\left(\mathrm{Pg},{ }^{* * *} p=0.0003\right)$, and further refined after hearing onset 0.0238 ) and mature by adulthood ( $8-10$ weeks, $* p=0.0286$, Mann-Whitney test). In contrast, the ribbon with WT pillar ribbon sizes (* $p \leq 0.0159$, Mann-Whitney test), and resemble modiolar ribbon volumes at all ages examined. Refinement of modiolar-face ribbon size is delayed in APC CKOs (P9 and P28). Adult data are replotted from Figure 2 for age comparison. Scale bar, $5 \mu \mathrm{m}$. P9: $n=5$ APC cK0s and 8 WTs; P28: $n=5$ APC cKOs and 6 WTs. Error bars represent SEMs. $\boldsymbol{b}$, Flattened confocal $z$-stacks of cochlea whole mounts in the $16 \mathrm{kHz}$ region show the base of IHCs immunolabeled for ribbons (red, MPAR patches compared with WT littermates. At P9, before dendritic pruning is complete, there are more GluR patches than ribbons, while in adults there is typically one ribbon per GluR patch. Scale bar, $10 \mu \mathrm{m} . n=2-5 \mathrm{cKOs}, n=4-5$ WTs.

synapses on IHC somata, and lateral OC (LOC) efferents establish axodendritic synapses on SGNs (Simmons et al., 1996; Pujol et al., 1998; Katz et al., 2004; Bulankina and Moser, 2012). Our Cre expression data suggest that APC is deleted in both OC neuron subgroups. Consistent with this expression pattern, we observe altered presynaptic terminal differentiation of both cholinergic and dopaminergic efferent inputs within the ISB of neonatal APC cKO cochleae. $\alpha 9 / 10$-Subunit-containing nAChRs and small-conductance calcium-activated potassium channels (SK2s) cofunction at the nicotinic synapse formed by OCs onto IHCs and OHCs. Gain-of-function and loss-of-function genetic perturbations of these channels demonstrate that nicotinic synaptic signaling regulates maturation of the OHC-based cochlear amplifier (and thus of cochlear frequency selectivity and the tonotopic map), as well as $\mathrm{Ca}^{2+}$ sensitivity of vesicle fusion at 

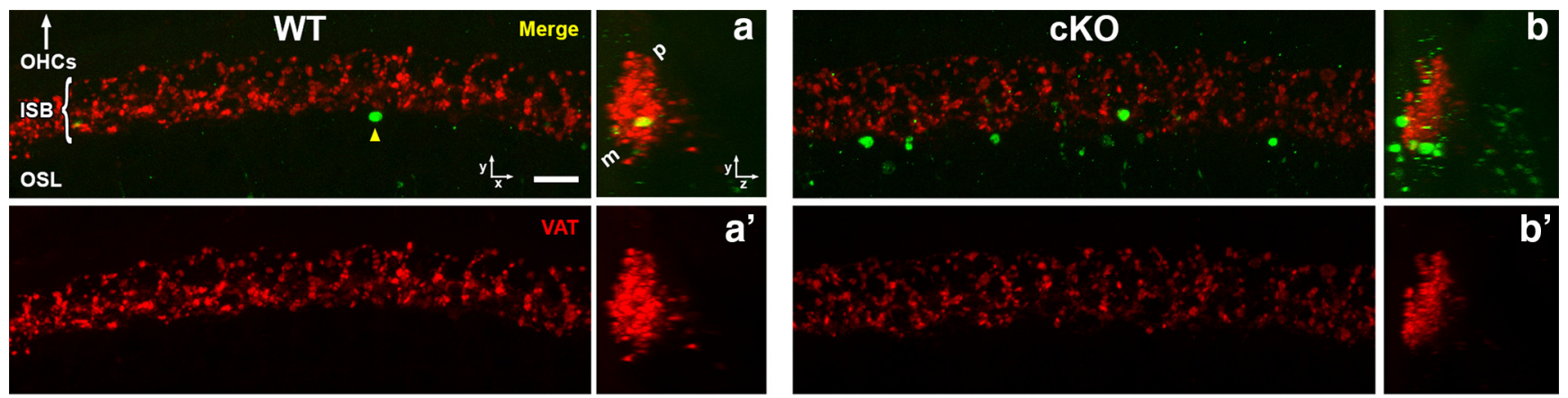

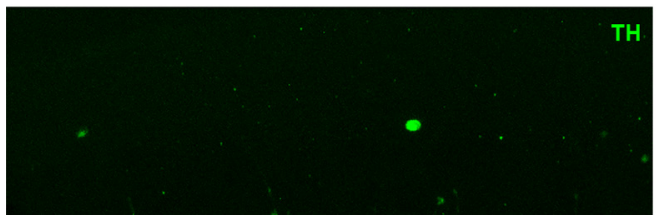

VAT
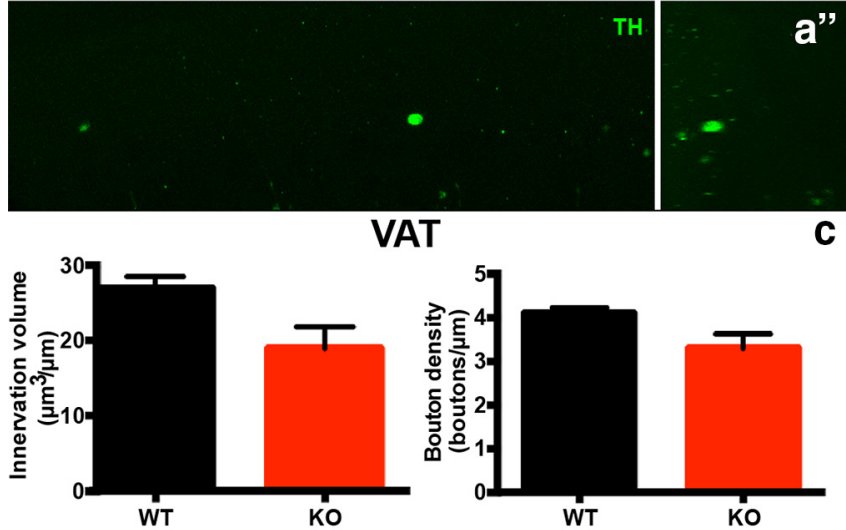

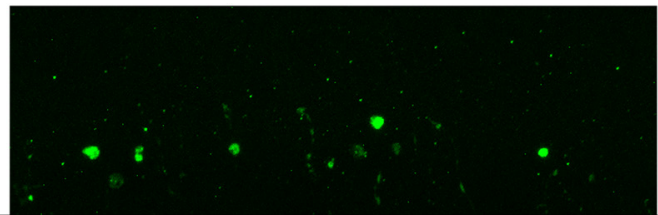

TH

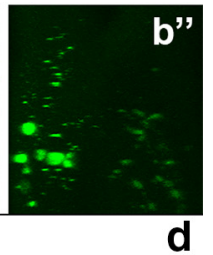

d

Figure 6. Efferent $O C$ presynaptic terminals are altered in neonatal APC cKO cochleae. $\boldsymbol{a}, \boldsymbol{b}$, Flattened, confocal $z$-stacks in $x$-y (left) and $y$-z (right) orientations show immunolabeled cholinergic (red, VAT) and dopaminergic (green, TH) efferent OC presynaptic boutons in the $16 \mathrm{kHz}$ region of P10 WT (a) and APC cKO (b) cochlea epithelial whole mounts. TH-immunolabeled boutons are larger and more common on the modiolar (m) side of the ISB in APC CKOs ( $(\boldsymbol{b})$, compared with WT littermates $(\boldsymbol{a})$. Smaller TH boutons are seen in the osseous spiral lamina (OSL). $\boldsymbol{a}^{\prime}, \boldsymbol{a}^{\prime \prime}, \boldsymbol{b}^{\prime}, \boldsymbol{b}^{\prime \prime}$, VAT ( $\left.\boldsymbol{a}^{\prime}, \boldsymbol{b}^{\prime}\right)$ and TH $\left(\boldsymbol{a}^{\prime \prime}, \boldsymbol{b}^{\prime \prime}\right)$ channels from these same micrographs are displayed alone for increased clarity. Scale bar: $\boldsymbol{a}, \boldsymbol{b}, 10 \mu \mathrm{m}$. $\boldsymbol{c}, \boldsymbol{d}$, Volumetric analysis of VAT-labeled (c) and TH-labeled (d) efferent terminals in the $16 \mathrm{kHz}$ region of the ISB. VAT-positive terminals show a trend to reduced volume in APC $c$ KOs. TH boutons are significantly increased in volume and density (d). $n=5$ APC $c K 0$ s and 3 WTs. Error bars represent SEMs. ${ }^{*} p=0.011,{ }^{* *} p=0.0049$, unpaired $t$ test.

IHC ribbon synapses (Walsh et al., 1998; Fettiplace and Fuchs, 1999; Vetter et al., 1999, 2007; Marcotti et al., 2004; Johnson et al., 2007, 2013). Despite these changes, neural thresholds are not altered in mice with SK2 or nAChR subunit genetic manipulations (Vetter et al., 1999, 2007; Johnson et al., 2007; Murthy et al., 2009). Thus, the increased thresholds in APC cKO mice are not likely due to the trend to reduced cholinergic innervation.

LOC efferent inputs onto SGN dendrites modulate postsynaptic firing rates, and refine ribbon synapse function (Felix and Ehrenberger, 1992; Ruel et al., 2001; Groff and Liberman, 2003; Darrow et al., 2006b, 2007; Vetter et al., 2007; Yin et al., 2014). LOC inputs consist of distinct excitatory and inhibitory subpopulations (Groff and Liberman, 2003; Darrow et al., 2006a,b). Our analysis of markers for the excitatory (cholinergic, VAT) and inhibitory (dopaminergic, $\mathrm{TH}$ ) inputs show a significant increase in volume and density of dopaminergic terminals in neonatal APC cKO mice, suggesting increased efferent inhibition. Further, in both APC cKOs and WT littermates, TH puncta are larger and more common on the modiolar side of the ISB (Fig. $6 a, b$ ), suggesting that polarization of the dopaminergic inputs may regulate the polarized differentiation of afferent ribbon sizes, AMPAR cluster size, and SGN SRs along the modiolar-pillar axis. Coupled with the afferent ribbon synaptic changes, our data indicate that APC and efferent OC innervation play an essential role in directing the differentiation of auditory synapses.

In the adult mouse cochlea, maintenance of ribbon synapse gradients requires OC synapses on SGNs. Surgical interruption of the OC bundle in adult mice leads to loss of complementary ribbon and AMPAR patch size gradients and a reduced SR range
(Liberman, 1990; Yin et al., 2014). The effects of adult deefferentation suggest that LOC efferents modulate postsynaptic firing rates and that loss of this modulation retrogradely influences presynaptic ribbon morphology (Liberman, 1990; Yin et al., 2014).

Interestingly, ribbon size is regulated by $\mathrm{Ca}^{2+}$ influx through L-type voltage-gated $\mathrm{Ca}^{2+}$ channels, but not by neurotransmission, during a critical developmental window in zebrafish lateralline hair cells and in pinealocytes (Sheets et al., 2012). If a similar mechanism operates in the mammalian cochlea, APC loss from efferent OCs may cause abnormal $\mathrm{Ca}^{2+}$ influx and L-type $\mathrm{Ca}^{2+}$ channel levels and/or localization in IHCs at neonatal ages and thereby lead to afferent ribbon synapse dysmorphology. Structural and functional refinements of cochlear ribbon synapses are regulated by maturation of $\mathrm{CaV} 1.3$ channel clustering at active zones, emergence of stronger $\mathrm{Ca}^{2+}$ signals, tighter spatial coupling between $\mathrm{Ca}^{2+}$ influx and exocytosis in IHCs, and by altered postsynaptic properties and higher spontaneous spike rates in SGNs (Ruel et al., 2001; Liberman et al., 2011; Huang et al., 2012; Wong et al., 2013, 2014).

At interneuronal and nerve-muscle synapses, APC organizes a multiprotein synaptic complex that is essential for proper maturation (Wang et al., 2003; Temburni et al., 2004; Rosenberg et al., 2008, 2010; Mohn et al., 2014). Blocking APC function in only one of the two synaptic partners at interneuronal nicotinic synapses leads to changes in both presynaptic and postsynaptic specializations, including decreases in nAChR clusters, actively recycling synaptic vesicles, active zone proteins, and neurexin and neuroligin adhesion molecules (Temburni et al., 2004; 
Rosenberg et al., 2008, 2010). In hippocampal neurons, APC cKO leads to increases in the frequency of AMPA-mediated miniature EPSPs at glutamatergic synapses (Mohn et al., 2014). Molecular changes caused by APC cKO in central neurons include altered levels of $\beta$-catenin and its associated pathways of canonical Wnt signal transduction and cadherin-based intercellular adhesion (Mohn et al., 2014). Both pathways signal bidirectionally at interneuronal synapses and neuromuscular junctions to modulate synaptic density, size, function, maturation, and plasticity (Togashi et al., 2002; Li et al., 2008; Koles and Budnik, 2012; Salinas, 2012; Mohn et al., 2014). Our findings at the sensory hair cell ribbon synapse, together with the role of APC at interneuronal and nerve-muscle synapses, suggest a global role for APC in directing the proper maturation of synapses in diverse cell types.

Hearing abnormalities have been reported in only some patients with APC loss-of-function gene mutations (Lutz et al., 2006; Jones et al., 2010). The precise mutations were not mapped in the small cohort tested for hearing. Unfortunately, this prevents determining whether hearing loss correlates with APC deletions, but possibly not with truncations or point mutations that may have milder effects. Intellectual disabilities, ranging from severe to mild, and autism spectrum disorders are associated with APC heterozygous gene deletions (Hockey et al., 1989; Cross et al., 1992; Raedle et al., 2001; Heald et al., 2007; Zhou et al., 2007). Reduced hearing, as a potential comorbidity, would significantly impact these individuals.

\section{References}

Bulankina AV, Moser T (2012) Neural circuit development in the mammalian cochlea. Physiology 27:100-112. CrossRef Medline

Cross I, Delhanty J, Chapman P, Bowles LV, Griffin D, Wolstenholme J, Bradburn M, Brown J, Wood C, Gunn A (1992) An intrachromosomal insertion causing 5q22 deletion and familial adenomatous polyposis coli in two generations. J Med Genet 29:175-179. CrossRef Medline

Darrow KN, Simons EJ, Dodds L, Liberman MC (2006a) Dopaminergic innervation of the mouse inner ear: evidence for a separate cytochemical group of cochlear efferent fibers. J Comp Neurol 498:403-414. CrossRef Medline

Darrow KN, Maison SF, Liberman MC (2006b) Cochlear efferent feedback balances interaural sensitivity. Nat Neurosci 9:1474-1476. CrossRef Medline

Darrow KN, Maison SF, Liberman MC (2007) Selective removal of lateral olivocochlear efferents increases vulnerability to acute acoustic injury. J Neurophysiol 97:1775-1785. Medline

Fearnhead NS, Britton MP, Bodmer WF (2001) The ABC of APC. Hum Mol Genet 10:721-733. CrossRef Medline

Felix D, Ehrenberger K (1992) The efferent modulation of mammalian inner hair cell afferents. Hear Res 64:1-5. CrossRef Medline

Fettiplace R, Fuchs PA (1999) Mechanisms of hair cell tuning. Annu Rev Physiol 61:809-834. CrossRef Medline

Furman AC, Kujawa SG, Liberman MC (2013) Noise-induced cochlear neuropathy is selective for fibers with low spontaneous rates. J Neurophysiol 110:577-586. CrossRef Medline

Gómez-Casati ME, Murtie J, Taylor B, Corfas G (2010) Cell-specific inducible gene recombination in postnatal inner ear supporting cells and glia. JARO 11:19-26. CrossRef Medline

Gounari F, Chang R, Cowan J, Guo Z, Dose M, Gounaris E, Khazaie K (2005) Loss of adenomatous polyposis coli gene function disrupts thymic development. Nat Immunol 6:800-809. CrossRef Medline

Grant L, Yi E, Glowatzki E (2010) Two modes of release shape the postsynaptic response at the inner hair cell ribbon synapse. J Neurosci 30:42104220. CrossRef Medline

Groff JA, Liberman MC (2003) Modulation of cochlear afferent response by the lateral olivocochlear system: activation via electrical stimulation of the inferior colliculus. J Neurophysiol 90:3178-3200. CrossRef Medline

Heald B, Moran R, Milas M, Burke C, Eng C (2007) Familial adenomatous polyposis in a patient with unexplained mental retardation. Nat Clin Pract Neurol 3:694-700. CrossRef Medline

Hockey KA, Mulcahy MT, Montgomery P, Levitt S (1989) Deletion of chromosome $5 \mathrm{q}$ and familial adenomatous polyposis. J Med Genet 26:61-62. CrossRef Medline

Huang LC, Barclay M, Lee K, Peter S, Housley GD, Thorne PR, Montgomery JM (2012) Synaptic profiles during neurite extension, refinement and retraction in the developing cochlea. Neural Dev 7:38. CrossRef Medline

Johnson SL, Marcotti W, Kros CJ (2005) Increase in efficiency and reduction in $\mathrm{Ca} 2+$ dependence of exocytosis during development of mouse inner hair cells. J Physiol 563:177-191. CrossRef Medline

Johnson SL, Adelman JP, Marcotti W (2007) Genetic deletion of SK2 channels in mouse inner hair cells prevents the developmental linearization in the Ca2+ dependence of exocytosis. J Physiol 583:631-646. CrossRef Medline

Johnson SL, Kuhn S, Franz C, Ingham N, Furness DN, Knipper M, Steel KP, Adelman JP, Holley MC, Marcotti W (2013) Presynaptic maturation in auditory hair cells requires a critical period of sensory-independent spiking activity. Proc Natl Acad Sci U S A 110:8720-8725. CrossRef Medline

Jones SE, Joice P, Cochrane L, Thoresen I, Quyn A, Nähke I (2010) Is familial adenomatous polyposis associated with sensorineural hearing loss? Int J Audiol 49:762-764. CrossRef Medline

Katz E, Elgoyhen AB, Gómez-Casati ME, Knipper M, Vetter DE, Fuchs PA, Glowatzki E (2004) Developmental regulation of nicotinic synapses on cochlear inner hair cells. J Neurosci 24:7814-7820. CrossRef Medline

Khimich D, Nouvian R, Pujol R, Tom Dieck S, Egner A, Gundelfinger ED, Moser T (2005) Hair cell synaptic ribbons are essential for synchronous auditory signalling. Nature 434:889-894. CrossRef Medline

Koles K, Budnik V (2012) Wnt signaling in neuromuscular junction development. Cold Spring Harb Perspect Biol 4:a008045. CrossRef Medline

Li XM, Dong XP, Luo SW, Zhang B, Lee DH, Ting AK, Neiswender H, Kim CH, Carpenter-Hyland E, Gao TM, Xiong WC, Mei L (2008) Retrograde regulation of motoneuron differentiation by muscle beta-catenin. Nat Neurosci 11:262-268. CrossRef Medline

Liberman LD, Wang H, Liberman MC (2011) Opposing gradients of ribbon size and AMPA receptor expression underlie sensitivity differences among cochlear-nerve/hair-cell synapses. J Neurosci 31:801-808. CrossRef Medline

Liberman MC (1978) Auditory-nerve response from cats raised in a lownoise chamber. J Acoust Soc Am 63:442-455. CrossRef Medline

Liberman MC (1982) Single-neuron labeling in the cat auditory nerve. Science 216:1239-1241. CrossRef Medline

Liberman MC (1990) Effects of chronic cochlear de-efferentation on auditory-nerve response. Hear Res 49:209-223. CrossRef Medline

Lin HW, Furman AC, Kujawa SG, Liberman MC (2011) Primary neural degeneration in the Guinea pig cochlea after reversible noise-induced threshold shift. JARO 12:605-616. CrossRef Medline

Lutz TA, Lopez R, Burke CA, Lynch P, Hawk E, Griebel D, Phillips R, Latchford A, Hennie $\mathrm{H}$ (2006) Is hearing loss an extracolonic manifestation of FAP? Am J Gastroenterol 101:S554-S561. CrossRef

Marcotti W, Johnson SL, Kros CJ (2004) A transiently expressed SK current sustains and modulates action potential activity in immature mouse inner hair cells. J Physiol 560:691-708. CrossRef Medline

Mogensen MM, Tucker JB, Mackie JB, Prescott AR, Näthke IS (2002) The adenomatous polyposis coli protein unambiguously localizes to microtubule plus ends and is involved in establishing parallel arrays of microtubule bundles in highly polarized epithelial cells. J Cell Biol 157:1041-1048. CrossRef Medline

Mohn JL, Alexander J, Pirone A, Palka CD, Lee SY, Mebane L, Haydon PG, Jacob MH (2014) Adenomatous polyposis coli protein deletion leads to cognitive and autism-like disabilities. Mol Psychiatry 19:1133-1142. CrossRef Medline

Moser T, Beutner D (2000) Kinetics of exocytosis and endocytosis at the cochlear inner hair cell afferent synapse of the mouse. Proc Natl Acad Sci U S A 97:883-888. CrossRef Medline

Murthy V, Maison SF, Taranda J, Haque N, Bond CT, Elgoyhen AB, Adelman JP, Liberman MC, Vetter DE (2009) SK2 channels are required for function and long-term survival of efferent synapses on mammalian outer hair cells. Mol Cell Neurosci 40:39-49. CrossRef Medline

Muzumdar MD, Tasic B, Miyamichi K, Li L, Luo L (2007) A global doublefluorescent Cre reporter mouse. Genesis 45:593-605. CrossRef Medline

Preitner N, Quan J, Nowakowski DW, Hancock ML, Shi J, Tcherkezian J, 
Young-Pearse TL, Flanagan JG (2014) APC is an RNA-binding protein, and its interactome provides a link to neural development and microtubule assembly. Cell 158:368-382. CrossRef Medline

Pujol R, Lavigne-Rebillard M, Lenoir M (1998) Development of sensory and neural structures in the mammalian cochlea. In: Springer handbook of auditory research: development of the auditory system, pp 146-192. New York: Springer New York.

Raedle J, Friedl W, Engels H, Koenig R, Trojan J, Zeuzem S (2001) A de novo deletion of chromosome $5 \mathrm{q}$ causing familial adenomatous polyposis, dysmorphic features, and mild mental retardation. Am J Gastroenterol 96: 3016-3020. CrossRef Medline

Rios M, Fan G, Fekete C, Kelly J, Bates B, Kuehn R, Lechan RM, Jaenisch R (2001) Conditional deletion of brain-derived neurotrophic factor in the postnatal brain leads to obesity and hyperactivity. Mol Endocrinol 15: 1748-1757. CrossRef Medline

Rosenberg MM, Yang F, Giovanni M, Mohn JL, Temburni MK, Jacob MH (2008) Adenomatous polyposis coli plays a key role, in vivo, in coordinating assembly of the neuronal nicotinic postsynaptic complex. Mol Cell Neurosci 38:138-152. CrossRef Medline

Rosenberg MM, Yang F, Mohn JL, Storer EK, Jacob MH (2010) The postsynaptic adenomatous polyposis coli (APC) multiprotein complex is required for localizing neuroligin and neurexin to neuronal nicotinic synapses in vivo. J Neurosci 30:11073-11085. CrossRef Medline

Roux I, Wersinger E, McIntosh JM, Fuchs PA, Glowatzki E (2011) Onset of cholinergic efferent synaptic function in sensory hair cells of the rat cochlea. J Neurosci 31:15092-15101. CrossRef Medline

Ruel J, Nouvian R, Gervais d'Aldin C, Pujol R, Eybalin M, Puel JL (2001) Dopamine inhibition of auditory nerve activity in the adult mammalian cochlea. Eur J Neurosci 14:977-986. CrossRef Medline

Ruel J, Wang J, Rebillard G, Eybalin M, Lloyd R, Pujol R, Puel JL (2007) Physiology, pharmacology and plasticity at the inner hair cell synaptic complex. Hear Res 227:19-27. CrossRef Medline

Salinas PC (2012) Wnt signaling in the vertebrate central nervous system: from axon guidance to synaptic function. Cold Spring Harb Perspect Biol 4:a008003. CrossRef Medline

Schmitz F, Königstorfer A, Südhof TC (2000) RIBEYE, a component of synaptic ribbons: a protein's journey through evolution provides insight into synaptic ribbon function. Neuron 28:857-872. CrossRef Medline

Sendin G, Bulankina AV, Riedel D, Moser T (2007) Maturation of ribbon synapses in hair cells is driven by thyroid hormone. J Neurosci 27:31633173. CrossRef Medline

Sheets L, Kindt KS, Nicolson T (2012) Presynaptic CaV1.3 channels regulate synaptic ribbon size and are required for synaptic maintenance in sensory hair cells. J Neurosci 32:17273-17286. CrossRef Medline

Simmons DD, Mansdorf NB, Kim JH (1996) Olivocochlear innervation of inner and outer hair cells during postnatal maturation: evidence for a waiting period. J Comp Neurol 370:551-562. CrossRef3.0.CO;2-M Medline

Simmons D, Duncan J, de Caprona DC, Fritzsch B (2011) Development of the inner ear efferent system. In: Springer handbook of auditory research: auditory and vestibular efferents, pp 187-216. New York: Springer New York.

Soriano P (1999) Generalized lacZ expression with the ROSA26 Cre reporter strain. Nat Genet 21:70-71. CrossRef Medline

Spoendlin H (1972) Innervation densities of the cochlea. Acta Otolaryngol 73:235-248. CrossRef Medline

Taberner AM, Liberman MC (2005) Response properties of single auditory nerve fibers in the mouse. J Neurophysiol 93:557-569. Medline

Temburni MK, Rosenberg MM, Pathak N, McConnell R, Jacob MH (2004) Neuronal nicotinic synapse assembly requires the adenomatous polyposis coli tumor suppressor protein. J Neurosci 24:6776-6784. CrossRef Medline

Togashi H, Abe K, Mizoguchi A, Takaoka K, Chisaka O, Takeichi M (2002) Cadherin regulates dendritic spine morphogenesis. Neuron 35:77-89. CrossRef Medline

Tritsch NX, Yi E, Gale JE, Glowatzki E, Bergles DE (2007) The origin of spontaneous activity in the developing auditory system. Nature 450:50-55. CrossRef Medline

Tsuji J, Liberman MC (1997) Intracellular labeling of auditory nerve fibers in guinea pig: central and peripheral projections. J Comp Neurol 381: 188-202. CrossRef Medline

Vetter DE, Liberman MC, Mann J, Barhanin J, Boulter J, Brown MC, SaffioteKolman J, Heinemann SF, Elgoyhen AB (1999) Role of alpha9 nicotinic ACh receptor subunits in the development and function of cochlear efferent innervation. Neuron 23:93-103. CrossRef Medline

Vetter DE, Katz E, Maison SF, Taranda J, Turcan S, Ballestero J, Liberman MC, Elgoyhen AB, Boulter J (2007) The alpha10 nicotinic acetylcholine receptor subunit is required for normal synaptic function and integrity of the olivocochlear system. Proc Natl Acad Sci U S A 104:20594-20599. CrossRef Medline

Walsh EJ, McGee J, McFadden SL, Liberman MC (1998) Long-term effects of sectioning the olivocochlear bundle in neonatal cats. J Neurosci 18: 3859-3869. Medline

Wang J, Jing Z, Zhang L, Zhou G, Braun J, Yao Y, Wang ZZ (2003) Regulation of acetylcholine receptor clustering by the tumor suppressor APC. Nat Neurosci 6:1017-1018. CrossRef Medline

Wong AB, Jing Z, Rutherford MA, Frank T, Strenzke N, Moser T (2013) Concurrent maturation of inner hair cell synaptic $\mathrm{Ca}^{2+}$ influx and auditory nerve spontaneous activity around hearing onset in mice. J Neurosci 33:10661-10666. CrossRef Medline

Wong AB, Rutherford MA, Gabrielaitis M, Pangrsic T, Göttfert F, Frank T, Michanski S, Hell S, Wolf F, Wichmann C, Moser T (2014) Developmental refinement of hair cell synapses tightens the coupling of $\mathrm{Ca} 2+$ influx to exocytosis. EMBO J 33:247-264. CrossRef Medline

Yin Y, Liberman LD, Maison SF, Liberman MC (2014) Olivocochlear innervation maintains the normal modiolar-pillar and habenular-cuticular gradients in cochlear synaptic morphology. JARO 15:571-583. CrossRef Medline

Yuan Y, Shi F, Yin Y, Tong M, Lang H, Polley DB, Liberman MC, Edge AS (2014) Ouabain-induced cochlear nerve degeneration: synaptic loss and plasticity in a mouse model of auditory neuropathy. JARO 15:31-43. CrossRef Medline

Yu X, Malenka RC (2004) Multiple functions for the cadherin/catenin complex during neuronal development. Neuropharmacology 47:779-786. CrossRef Medline

Zenisek D, Davila V, Wan L, Almers W (2003) Imaging calcium entry sites and ribbon structures in two presynaptic cells. J Neurosci 23:2538-2548. Medline

Zhou XL, Giacobini M, Anderlid BM, Anckarsäter H, Omrani D, Gillberg C, Nordenskjöld M, Lindblom A (2007) Association of adenomatous polyposis coli (APC) gene polymorphisms with autism spectrum disorder (ASD). Am J Med Genet B Neuropsychiatr Genet 144B:351-354. CrossRef Medline

Zuccotti A, Kuhn S, Johnson SL, Franz C, Singer W, Hecker D, Geisler HS, Köpschall I, Rohbock K, Gutsche K, Dlugaiczyk J, Schick B, Marcotti W, Rüttiger L, Schimmang T, Knipper M (2012) Lack of brain-derived neurotrophic factor hampers inner hair cell synapse physiology, but protects against noise-induced hearing loss. J Neurosci 32:8545-8553. CrossRef Medline 